\title{
PEDAGOGY
}

\section{The problem of forming the culture of speech of international students while studying in Ukraine}

\author{
L. Byan \\ Sumy State A. S. Makarenko Pedagogical University, Sumy, Ukraine \\ Corresponding author. E-mail: potdr2019@gmail.com \\ Paper received 30.01.20; Accepted for publication 18.01.20.
}

\begin{abstract}
https://doi.org/10.31174/SEND-PP2020-220VIII88-01
\end{abstract}
\begin{abstract}
This paper reveals the issues of forming the culture of speech of international students during professional training in higher education institutions in Ukraine. Concepts such as culture of speech, dialogue and etiquette are covered, as well as the phenomenon of linguistic communication as a system of knowledge, patterns of behavior, values, specific situations of professional interaction, and ability to put them into practice to achieve organic results of common activity. The paper also emphasizes that the "normative" speech of international students is the speech: which conforms to the language system, does not contradict its laws; in which the variant of the norm has new semantic-stylistic possibilities, expresses, refines the context; in which the applicable rules of another style are properly justified; in which mixing of norms of different languages under the influence of speech practice is not allowed.
\end{abstract}

Keywords: studying in HEI, Ukrainian language, culture of speech, international students, vocational training.

Nowadays, one of the main objectives in educational systems of many countries is development of the culture of individual's speech. This is due to the influence of communicatively acceptable language, building on understanding between people and appropriate interaction between representatives of different cultures. The level of individual's culture of speech is mainly judged based on emotional, intellectual culture and on general cultural status of the society as a whole.

At present, training of highly qualified specialists among international students in higher education institutions is an urgent problem while teaching the Ukrainian language and culture. It is about the importance of educating professionals who are able to use the Ukrainian language competently, capable to use the techniques and methods of effective communication, to communicate in the scientific as well as official and business spheres in Ukrainian in the countries all over the world and be competitive both in the Ukrainian labor market and abroad.

In Ukrainian higher education institutions, every year there is an increase in percentage of international students who, in addition to special knowledge (knowledge related to their profession), acquire experience in speaking Ukrainian, study in the framework of the program "Ukrainian as a Foreign Language", and receive diplomas of the established model. But, unfortunately, the basic course of Ukrainian does not provide an opportunity to cover such topics as: "Business Ukrainian Language", "Rules of Ukrainian Business Etiquette", "Business Correspondence" and others. In this regard, it is necessary to develop a special approach to teaching Ukrainian language and culture to foreign language students at an advanced stage, to provide all kinds of linguistic support in order to increase the level of knowledge of the Ukrainian language, in particular in the field of business and professional communication. It is important at all stages of learning to improve the language culture, to learn to use the Ukrainian language, and to communicate in various spheres of activity. It should be emphasized that, when working with international students, we must take into account the specifics of language acquisition of this category of students and use more productive methods of teaching Ukrainian language and culture of speech.

The study of culture of speech originates from the works of such eminent scholars as M.V. Lomonosov, A. Kh. Vostokova, V.O. Suhomlinsky, K.D. Ushinsky and others. Speech culture as a scientific discipline in the twentieth century developed mainly within orthological directions (right/wrong). The theory of norm and normativity, systematics of speech norms formed in the works of such philologists as G.O. Vinokur, S.O. Karaman, L.I. Matsko, S.I. Ozhegov. This trend in the 21st century was developed by such researchers as A.D. Ponomarev, M.Ya. Pliushch, L.M. Savich, L.I. Skvortsov, I.P. Yushchuk and others.

Increasing the level of linguistic and speech culture was brought up in works of such linguists as I.K. Bilodid, N.D. Babich, D.I. Hanych, A.P. Koval, M.I. Pentilyuk, V.M. Rusanovsky, S. Ya. Yermolenko and others. Psychological aspects of this problem are reflected in the works of such researchers as L.I. Aydarova, D.M. Bogoyavlensky, L.S. Vygotsky, G.S. Kostyuk, O.O. Leontiev, and others. According to these scholars, the essence of the theory of speech activity is that any speech act is defined as a specific type of activity (communicative), which begins with a motive and ends with the result, the achievement of the goal. Of particular importance are studies of speech activity by I.O. Sinitsa, which reveal the patterns of speech communication, the content and tasks of vocabulary. Pedagogical and methodological bases of work on enrichment and development of vocabulary, enhancement of the culture of speech of students were developed by F.I. Buslayev, I.I. Sreznevsky. Of great importance are the works by philologists M.G. Stelmakhovych, S. Ch. Chavdarov and others.

The analysis of scientific literature on the topic shows that a lot of attention has been paid to study of language culture. However, the methodological aspect of forming a culture of speech in international students studying at 
higher education institutions in Ukraine has not been sufficiently investigated both theoretically and practically.

The aim of the paper is to analyze the problems of forming speech culture of international students studying in Ukraine and to determine further ways of solving them.

Thus, at the moment, the culture of speech implies adherence to linguistic norms of pronunciation, emphasis, orthography and building word expressions, accuracy, clarity, purity, logical harmony, richness and appropriateness of speech, as well as to the rules of speech etiquette [5].

There are the following basic aspects of the expression of speech culture:

- normativity (observance of all rules of oral and written speech);

- adequacy (accuracy of expression, clarity and comprehensibility of speech);

- aesthetics (the use of expressive and stylistic language means that make speech rich and expressive);

- polyfunctionality (use of language in different spheres of life) [5].

A high level of speech culture requires perfect mastery of the literary language in the process of communication and advanced speech skills. The main quality communicative features, they are also called criteria, culture of speech are correctness, accuracy, logic, content, relevance, wealth, expressiveness, purity/

Studying the history of development of philosophical and psychological-pedagogical research has shown that scientists view communication as a process that embraces and organizes all aspects of human life. Its purpose is defined as the achievement of the results of joint communication activity. The specificity of linguistic communication, which distinguishes it from any other act of communication, lies precisely in coordination of the interests of those who communicate and achievement of a common goal [2].

Based on the analysis of theoretical fundamentals of formation of culture of communication, features of linguistic communication are identified, which determine different types of linguistic communication. Therefore, we define the phenomenon of linguistic communication as a system of knowledge, patterns of behavior, values, particular situations of professional interaction, and ability to apply them in practical communication in order to achieve organic results of cooperative activities.

In search for the best tools and techniques for learning Ukrainian as an instrument for future professional activity of international students, we came to conviction that communication skills and abilities are the dominant factor in the development of their culture of speech at all stages of learning, among which we consider formation of textual and literary skills to be most important element as a basis for building a coherent expression of different styles and genres. The more intensively students are involved in the process of mastering communication skills, the sooner they reach the level of adequate synthesis in mastering modern Ukrainian as a means of intercultural and professional communication.

Variation of educational activities leads to increased students' interest in learning the Ukrainian language, developing their thinking and improving linguistic competence.
Dialogue is traditionally cited among the most productive methods of studying normative Ukrainian. A purposeful system of exercises in solving problematic linguistic tasks underlies the effective formation of meaningful communication skills and habits of students, helping to prevent inaccuracies and errors in their speech. Learning by specific examples, foreign students are successfully mastering the patterns of correct speech using the simulation of life situations, mastering the art of language communication [1].

At the heart of the culture of human speech is its ability to engage in a dialogue that is built upon the mutual respect between the agents of communication, mutual interest, openness. It is well known that dialogue envisages the uniqueness of each partner and their fundamental equality with each other; the difference and originality of their points of view; orienting everyone to an understanding and active interpretation of the perspectives of both; anticipation of the response and its prediction in one's own statement; mutual "complementarity" of the positions of the participants of communication, the ratio of which is the purpose of the dialogue. That is why a dialogue can be a form of communication only between subjects, expressing precisely those features that distinguish the subject from the object.

It should be emphasized that when working with international students, we must take into account the specifics of learning of each category of students and use the most productive methods of teaching the Ukrainian language and language culture.

Let us consider another method of teaching Ukrainian normative language, namely the use of samples of oral speech in the texts of journalists, radio and television speakers, etc., since one of the areas of study of international students is the formation of auditory skills, the perception hearing the language and listening comprehension.

Street language contributes to enriching the vocabulary of international students, expanding the use of certain grammatical constructions, but it is everyday communication which cannot provide a positive experience to international students in regards to scientific, business or professional communication, besides it can lead to pollution of language and deviation from the normative use of its assets [4].

It is important for a specialist, a graduate of a higher education institution, to acquire the skills of masterful communication in these spheres, as well as to acquire the skills of normative use of the language, to consolidate those rules of use of linguistic units, which are specified in dictionaries. Therefore, the media play an important role in this situation, being a standard, a model for imitation in terms of the use of words, construction of linguistic structures, the use of different grammatical models in appropriate situations of communication, as well as the use of professional and scientific vocabulary in language.

Thus, in the Ukrainian language courses at HEIs, when working with international students at an advanced stage of education, we recommend to refer to the texts from the media, listening and analyzing the speech of native speakers, broadcasters, commentators, scientists and cultural activists. 
On the other hand, characterizing the current state of the Ukrainian language nowadays, we have to pay attention to the crisis phenomena related to the functional side of our language, as well as weak abilities to use its vast wealth, intonation and other possibilities. We live in an atmosphere of violation of all linguistic norms, and these violations often come from the mouths of those who have to speak normatively: journalists, figures of science and culture, politicians and others.

Linguistic norms are characterized by systematic, historical and social conditionality, stability. This last characteristic (stability) does not contradict the habitude of the literary norm to change over time. If in orthoepy, grammar the norms are oriented at a paragon, model, standard, in lexis, on the other hand, the implementation of the norm is also dependent on the content, that is it varies in each individual case based on the context. Spelling standards change from time to time according to the needs of the society to codify the spelling in view of new approaches. For example, spelling of words of foreign origin was subject to changes in order to bring them closer to Ukrainian pronunciation; the renewal of the use of the letter $\tau$ in written form of the words "ганок, гречний, гудзик, грати, обгрунтувати, прогавити” (porch, polite, button, bars, to substantiate, to miss); there have been changes to the capitalization of the names of cult books. The norms of literary language reinforce the traditions, cultural achievements of the past and, at the same time, regulate the use not only of established rules, but also the emergence of new ones in the process of speaking activities of international students [3].

The normative language of international students is characterized by the following features: 1) it corresponds to the language system, does not contradict its laws; 2) a variant of the norm has new semantic-stylistic properties, expresses, refines the context, gives additional and comprehensive information; 3 ) the applicable rules of another style are duly substantiated; 4) it does not allow mixing of different languages under the influence of speech practice. Summarizing all of the above, we can conclude that in higher education institutions at an advanced stage of studying Ukrainian as a foreign language, it is necessary to organize systematic and purposeful activities to develop and improve the language culture of international students, to find effective methods and forms of work, effective tools and techniques for developing communicative skills. It is necessary to build a rational system of exercises and tasks that require active work of the mind and at the same time linguistic intuition, to develop a system of didactic problem situations, which includes analysis, classification and correction of errors in the speech of international students. It can also be noted that a high culture of speech is impossible without observing the socalled speech etiquette, which includes being able to listen attentively with interest, never interrupting people, engaging in conversation tactfully, having comprehensible and clear speech, speaking with tolerance, respect, being polite. Etiquette regulates relationships between people and formulates requirements that are equal for all people, regardless of their social status. The verbal level of etiquette is the most important, namely speech etiquette and dialogue. Enhancing the speech culture, improving the ethics of communication is crucial for the whole society, with all its functional levers: educational institutions, science, schools, press, radio, television. The culture of speech is not only a philological but also a social problem: it is in one way or another connected with the most varied forms of communication in the modern world.

\section{ЛІТЕРАТУРА}

1. Бабич Н. Д. Основи культури мовлення. - Львів: Світ, 3. Кравець Л. В. Мацько Л. І. Культура української фахової 2005. $-232 \mathrm{c}$.

2. Гриценко Т. Б. Українська мова та культура мовлення: навч. посіб. - К.: Центр навчальної літератури, 2003. $536 \mathrm{c}$.

мови: навч. посіб. - Київ: ВЦ «Академія», 2007. - 360 с.

4. Мацько Л. І. Стилістика української мови. - К.: Вища школа, 2003. $-411 \mathrm{c}$.

5. Мацюк 3., Станкевич Н. Українська мова професійного спілкування: навч. посіб. - К.: Каравела, 2005. - 352 с.

\section{REFERENCES}

1. Babich, N. D. (2005). Fundamentals of the Culture of Speech. 3. Kravets, L. V. \& Matsko, L. I. (2007). Culture of the UkrainiLviv: Svit [in Ukrainian].

2. Gritsenko, T. B. (2003). Ukrainian Language and Culture of Speech: Educational Manual. Kyiv: Tsentr navchalnoi literatury [in Ukrainian]. an Professional Language: Educational Manual. Kyiv: VT «Akademiya» [in Ukrainian].

4. Matsko, L. I. (2003). Stylistics of the Ukrainian language. Kyiv: Vischa Shkola [in Ukrainian].

5. Matsuk, Z. \& Stankevich N. (2005). Ukrainian Language of Professional Communication. Kyiv: Karavella [in Ukrainian]. 